\title{
The origin of the warm groundwater near Lake Mývatn, NE Iceland, traced by stable isotopes
}

\author{
Finnbogi Óskarsson ${ }^{1, *}$ \\ ${ }^{1}$ Iceland GeoSurvey (ÍSOR), Grensásvegur 9, 108 Reykjavík, Iceland
}

\begin{abstract}
The origin of the warm groundwater which feeds Lake Mývatn is unknown, but it has been affected by volcanic episodes as well as geothermal activity and utilisation. In this contribution stable isotopes of hydrogen $\left({ }^{2} \mathrm{H}\right)$, oxygen $\left({ }^{18} \mathrm{O}\right)$, sulphur $\left({ }^{34} \mathrm{~S}\right)$, chlorine $\left({ }^{37} \mathrm{Cl}\right)$ and strontium $\left({ }^{86} \mathrm{Sr}\right.$ and $\left.{ }^{87} \mathrm{Sr}\right)$ in 20 groundwater and effluent samples from the Lake Mývatn area are used to constrain the origin of the warm groundwater. The results suggest that the warm groundwater is partly formed by mixing with geothermal effluent water and partly by mixing with geothermal steam.
\end{abstract}

\section{Introduction}

Lake Mývatn, NE Iceland, is a part of a large groundwater system within the northern volcanic zone, extending from Vatnajökull glacier in the south to the Atlantic Ocean in the north. The lake has two main basins; Syðriflói $\left(28.2 \mathrm{~km}^{2}\right)$ to the south into which flow approximately $17 \mathrm{~m}^{3} / \mathrm{s}$ of cold groundwater, and Ytriflói $\left(8.5 \mathrm{~km}^{2}\right)$ to the north which receives about $11 \mathrm{~m}^{3} / \mathrm{s}$ of cold and warm groundwater. The exact origin of the warm groundwater is unclear, but it is certainly related to the two geothermal areas in the vicinity; Krafla and Bjarnarflag, both of which have been exploited for power production for decades. The spent geothermal fluid is partly discharged on surface. In order to detect chemical pollution from the geothermal fluid, the chemical composition of water from the hot and cold springs feeding the Ytriflói basin has been monitored regularly since 2002, along with groundwater from several shallow wells and fissures in the area [1,2].

Several attempts have been made to trace the origin of the warm groundwater, both by injecting tracer compounds [3] and by studying the water composition [2, 4]. In this contribution, water samples from 20 of the annual monitoring sites for groundwater in the Mývatn area were analysed for stable isotopes, namely ${ }^{2} \mathrm{H}(\mathrm{D}),{ }^{18} \mathrm{O},{ }^{34} \mathrm{~S},{ }^{37} \mathrm{Cl}$ and ${ }^{87} / 86 \mathrm{Sr}$. The concentrations of all major components and several trace components were also determined, as part of the regular monitoring.

\section{Sampling and analysis}

Water was pumped from wells, springs and open fissures either by a permanent down-hole pump or a peristaltic pump. The samples were filtered through $0.2 \mu \mathrm{m}$ cellulose acetate

\footnotetext{
*Corresponding author: finnbogi.oskarsson@isor.is
} 
filters using a inline PTFE filter holder. Samples for stable isotopes and anions were not treated further, but samples for analysis of cation concentrations were preserved with $1 \%$ suprapur $\mathrm{HNO}_{3} . \mathrm{H}_{2} \mathrm{~S}$ concentrations, $\mathrm{pH}$, electrical conductivity, and temperature were determined on site, but samples for $\mathrm{CO}_{2}$ were collected into airtight glass bottles and analysed within 48 hours. All main constituents in the samples were analysed at the ÍSOR laboratory, $\delta \mathrm{D}$ and $\delta^{18} \mathrm{O}$ were determined at the Institute for Earth Sciences, University of Iceland, whereas $\delta^{34} \mathrm{~S}$ in $\mathrm{SO}_{4}, \delta^{37} \mathrm{Cl}$, and ${ }^{87} \mathrm{Sr} /{ }^{86} \mathrm{Sr}$ were measured at the University of Waterloo (Canada) Environmental Isotope Laboratory.

The sample locations are shown in Figure 1 and results are given in Table 1.

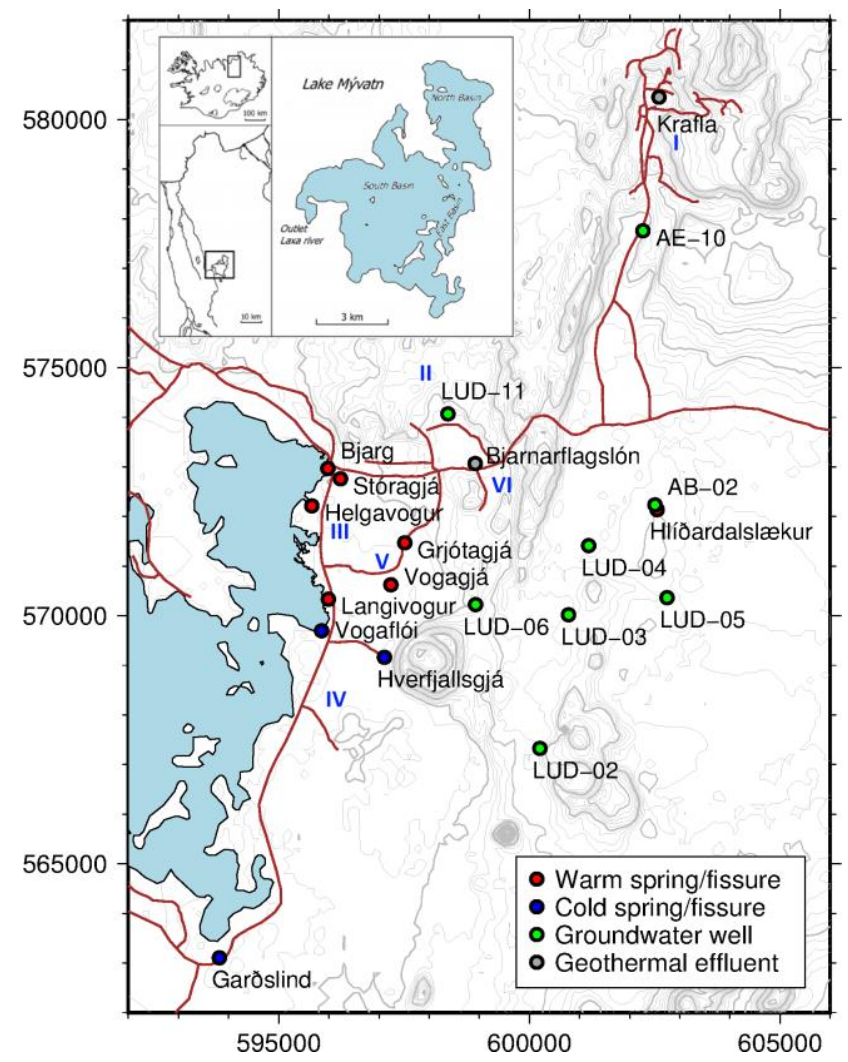

Fig. 1. Sample site location and classification. Water groups (roman numerals) follow the scheme of [4]. See Table 1 for grouping details.

\section{Results and discussion}

Following [4], the samples were divided into six different groups based on their temperature, deuterium content and location. The hydrogen and oxygen isotopes for all samples are shown in Figure 2 along with the local meteoric water line [5]. Samples from groups II and III represent warm and/or cold local groundwater with $\delta \mathrm{D}$ from -87 to $-85 \%$. Samples from group IV are more depleted $(\delta \mathrm{D}<-88 \%)$ and seem to be a part of the large groundwater current that flows from the south [4]. Samples from these three groups generally plot close to the meteoric water line. Samples from group V are warm waters with similar deuterium content as group IV waters, but with an oxygen isotope shift of about $+0.8 \%$ from the meteoric water line. Samples from groups I and VI represent geothermal 
effluent from the Krafla and Bjarnarflag power plants, respectively, and waters that have been heavily influenced by the effluent (Hlíðardalslækur and LUD-4). They show substantial oxygen isotope shift as well as effects of boiling.

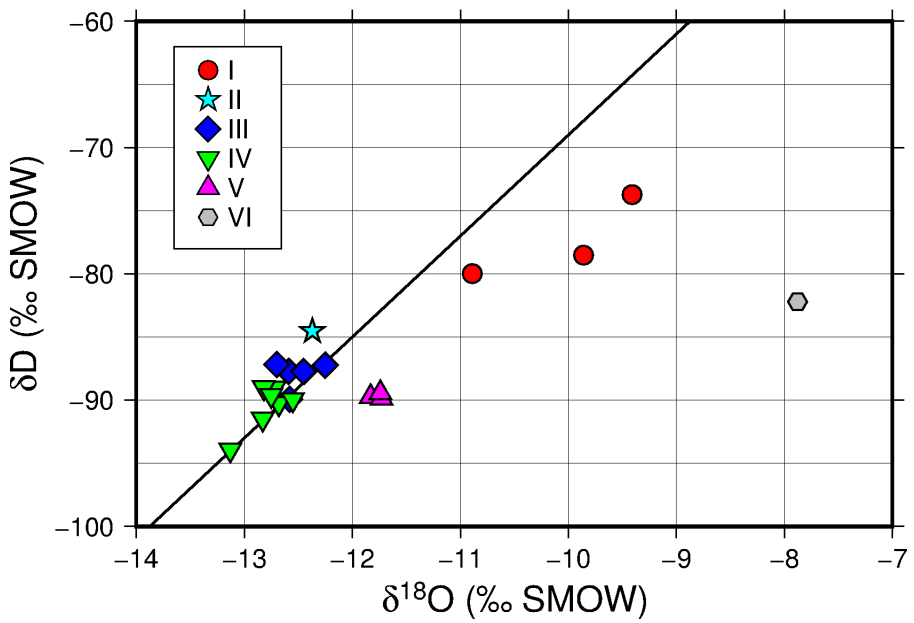

Fig. 2. Deuterium and oxygen-18 content of all samples, grouped by water type, along with the local meteoric water line [5].

The geographical distribution of sulphur, chlorine and strontium isotopes in samples from groups II, III, IV and V is given in Figure 3, interpolated by a spline algorithm. Samples from groups I and VI are omitted as they are strongly affected by effluent.
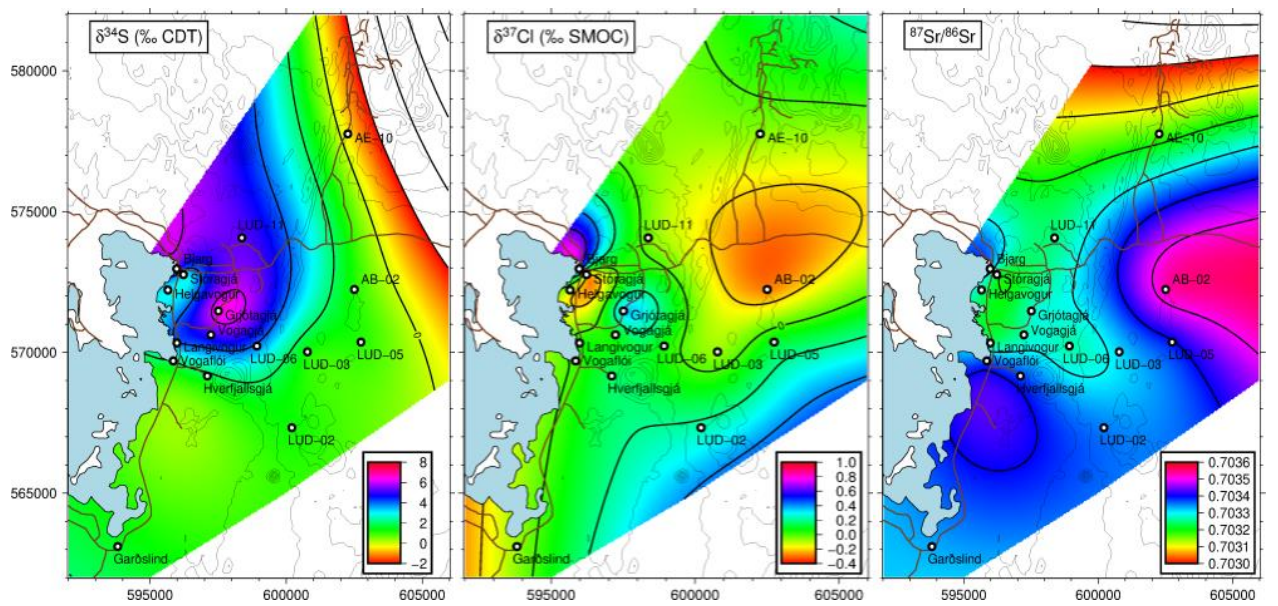

Fig. 3. Geographical distribution of $\mathrm{S}, \mathrm{Cl}$ and $\mathrm{Sr}$ isotopes in samples from groups II, III, IV and V.

The sulphur isotope values are quite similar $\left(\delta^{34} \mathrm{~S} \approx 1-2 \%\right.$ ) for all the cold water samples - as well as samples from group I. The samples from groups III and IV generally have rather low $\mathrm{SO}_{4}$ concentrations $(<30 \mathrm{mg} / \mathrm{L})$ whereas the samples from group I have $\mathrm{SO}_{4}$ concentrations ranging from 88 to $267 \mathrm{mg} / \mathrm{L}$. Sulphate concentrations in the warm groundwater samples from groups II, III, IV and V are higher $(49-125 \mathrm{mg} / \mathrm{L})$ than in the cold groundwater, and the samples are more enriched in ${ }^{34} \mathrm{~S}$ than the cold water samples $\left(\delta^{34} \mathrm{~S}\right.$ from 3.0 to $6.4 \%$ ) - with the exception of the sample from $\mathrm{AE}-10$, with $\delta^{34} \mathrm{~S} \approx-0.4 \%$ o and $69 \mathrm{mg} / \mathrm{L} \mathrm{SO}_{4}$. 
Sulphur isotope ratios in sulphate and sulphide in fluids from several production wells in Bjarnarflag and Krafla have been determined, with $\delta^{34} \mathrm{~S}$ ranges of -0.9 to $1.6 \%$ for $\mathrm{H}_{2} \mathrm{~S}$ and 7.6 to $8.6 \%$ for $\mathrm{SO}_{4}$ in Bjarnarflag, and -2.0 to $1.7 \%$ for $\mathrm{H}_{2} \mathrm{~S}$ and 2.7 to $13.4 \%$ o for $\mathrm{SO}_{4}$ in Krafla [6]. Samples of unaltered tholeiite from the northern volcanic zone have $\delta^{34} \mathrm{~S}$ from -2.0 to $0.0 \%$ o but values as high as $4.2 \%$ are observed for rhyolites [7].

The cold groundwater values fall within the reported $\delta^{34} \mathrm{~S}$ ranges in rocks, suggesting that the most important origin of sulphur in these samples is leaching of rocks. The warm groundwaters are more enriched in ${ }^{34} \mathrm{~S}$, suggesting mixing with a more enriched source. The observed values suggest that oxidation of geothermal sulphide is an unlikely source, but mixing with water containing geothermal sulphate is possible. An exception is the sample from AE-10 $\left(\delta^{34} \mathrm{~S}=-0.4 \%\right)$ in which sulphate could be formed by the oxidation of geothermal $\mathrm{H}_{2} \mathrm{~S}$. The $\delta^{34} \mathrm{~S}$ value obtained for the Bjarnarflagslón also compares well with results for sulphide in the boiled liquid phase from the Bjarnarflag wells [6].

The chlorine isotopes span a rather narrow range, with $\delta^{37} \mathrm{Cl}$ from -0.28 to $0.53 \%$. Indeed, almost all samples, including the geothermal brine endmembers, have $\delta^{37} \mathrm{Cl}$ between -0.2 and $0.2 \%$. The exceptions are AB-02 (-0.28\%), LUD-02 (0.23\%o), LUD-04 $(0.28 \%)$, Grjótagjá $(0.33 \%)$, and Bjarg $(0.53 \%)$. There does not seem to be a clear relationship between these outliers; AB-02 and LUD-02 represent pristine groundwaters from the east and south, respectively, whereas LUD-04 shows significant effects of mixing with Krafla waters even though the water is cold, and the samples from Grjótagjá and Bjarg are warm groundwaters.

Chlorine isotope results for several wells in Krafla, show $\delta^{37} \mathrm{Cl}$ ranging from 0.2 to $2.1 \%$, with an average of $0.9 \%$ [8]. No chlorine isotopes have been reported for well fluids from the Bjarnarflag field. Chlorine isotope data for basaltic glasses from the northern volcanic zone suggest a $\delta^{37} \mathrm{Cl}$ range of -0.4 to $0.6 \%$ [9]. Therefore, it seems that chloride in the groundwater mainly originates from dissolution of rocks.

The measured strontium isotope ratios $\left({ }^{87} \mathrm{Sr} /{ }^{86} \mathrm{Sr}\right)$ range from 0.70317 to 0.70353 and suggest a similar pattern as the sulphur isotopes; the cold samples from groups I and IV span a fairly narrow range (0.7033 to 0.7034$)$ - and so do the other group I samples and the sample from Bjarg. The warm samples from groups II, III, IV and V have a somewhat lower range (0.7032 to 0.7033$)$. The lowest strontium isotope ratio is observed in AE-10, but the sample from AB-02 has the highest isotope ratio.

Strontium isotope results for 14 rock samples from Krafla lavas dated from the last glacial period to 1984 range from 0.70309 to 0.70326 , with little difference between basalts and rhyolites [10]. Most of the samples presented here have somewhat higher ${ }^{87} \mathrm{Sr} /{ }^{86} \mathrm{Sr}$ ratios than the Krafla lavas.

\section{Conclusions}

An attempt was made to constrain the origin of the warm groundwater in the Lake Mývatn area by stable isotopes of hydrogen, oxygen, sulphur, chlorine and strontium. The water group classification of [4] is reproduced here. Sulphur and chlorine isotopes suggest that sulphate and chloride in the waters originate by leaching of rock. The former show correlation with temperature - as do the strontium isotopes - whereas the latter do not. The concentrations of $\mathrm{SO}_{4}$ and $\mathrm{Cl}$ suggest that the warm waters of groups II, III and IV are steam heated but the warm water in group $\mathrm{V}$ is formed by mixing with a geothermal endmember. Strontium isotopes suggest that this endmember is most likely the effluent from Bjarnarflag rather than Krafla - in agreement with $\delta \mathrm{D}$ and $\delta^{18} \mathrm{O}$. Results of tracer tests and conservative components $(\mathrm{B}, \mathrm{Cl})$ systematics have previously suggested the same $[2,3]$. 
Table 1. Measured temperature and stable isotope results for all samples.

\begin{tabular}{|c|c|c|c|c|c|c|c|}
\hline Sample site & Group & $\begin{array}{c}\mathbf{T} \\
\left({ }^{\circ} \mathrm{C}\right)\end{array}$ & $\begin{array}{c}\delta D \\
(\% \text { SMOW) }\end{array}$ & $\begin{array}{c}\delta^{18} \mathrm{O} \\
(\% \text { SMOW) }\end{array}$ & $\begin{array}{c}\delta^{34} \mathrm{~S} \\
\left(\%{ }_{0} \mathrm{CDT}\right)\end{array}$ & $\begin{array}{c}\delta^{37} \mathrm{Cl} \\
(\% \text { SMOC) }\end{array}$ & ${ }^{87} \mathrm{Sr} /{ }^{86} \mathrm{Sr}$ \\
\hline Hlíðardalslækur & I & 11.8 & -73.7 & -9.41 & 1.98 & 0.08 & 0.703379 \\
\hline Krafla & I & 93.5 & -78.5 & -9.86 & 2.13 & 0.13 & 0.703378 \\
\hline LUD-04 & I & 5.2 & -80.0 & -10.9 & 1.93 & 0.28 & 0.703320 \\
\hline LUD-11 & II & 33.1 & -84.5 & -12.4 & 5.27 & -0.04 & 0.703250 \\
\hline AB-02 & III & 2.9 & -87.7 & -12.6 & 1.17 & -0.28 & 0.703528 \\
\hline AE-10 & III & 39.0 & -87.2 & -12.7 & -0.43 & -0.06 & 0.703170 \\
\hline Bjarg & III & 19.0 & -89.9 & -12.6 & 5.08 & 0.53 & 0.703333 \\
\hline Helgavogur & III & 24.3 & -87.7 & -12.4 & 3.03 & -0.12 & 0.703261 \\
\hline Stóragjá & III & 27.6 & -87.2 & -12.2 & 3.16 & -0.13 & 0.703221 \\
\hline Garðslind & IV & 6.2 & -93.9 & -13.1 & 1.54 & -0.07 & 0.703333 \\
\hline Hverfjallsgjá & IV & 6.2 & -90.3 & -12.7 & 1.75 & 0.15 & 0.703375 \\
\hline LUD-02 & IV & 6.3 & -89.6 & -12.7 & 1.26 & 0.23 & 0.703351 \\
\hline LUD-03 & IV & 4.2 & -89.0 & -12.7 & 1.26 & -0.07 & 0.703315 \\
\hline LUD-05 & IV & 4.7 & -89.0 & -12.8 & 1.12 & 0.10 & 0.703395 \\
\hline LUD-06 & IV & 32.6 & -89.9 & -12.5 & 3.84 & 0.06 & 0.703268 \\
\hline Vogaflói & IV & 5.5 & -91.50 & -12.8 & 2.02 & 0.02 & 0.703367 \\
\hline Grjótagjá & $\mathrm{V}$ & 45.9 & -89.4 & -11.7 & 6.43 & 0.33 & 0.703279 \\
\hline Langivogur & V & 21.1 & -89.7 & -11.8 & 3.95 & 0.06 & 0.703246 \\
\hline Vogagjá & $\mathrm{V}$ & 40.9 & -89.90 & -11.7 & 5.01 & 0.07 & 0.703268 \\
\hline Bjarnarflagslón & VI & 21.4 & -82.2 & -7.88 & -0.88 & 0.09 & 0.703450 \\
\hline
\end{tabular}

This work and the annual monitoring on which it is based were carried out for Landsvirkjun Power, the operator of the Krafla and Bjarnarflag power plants. Their support is gratefully acknowledged.

\section{References}

1. H. Ármannsson, Proc. WGC, paper 0232 (2005)

2. M. Ólafsson, P. Friðriksson, P. H. Hafstað, S. S. Gylfadóttir, F. Óskarsson, H. Ármannsson, The effects of geothermal exploitation on the warm groundwater current to Lake Mývatn (in Icelandic), Iceland GeoSurvey report 2013/038, 42 (2013)

3. S. Hauksdóttir, H. Kristmannsdóttir, G. Axelsson, H. Ármannsson, H. Bjarnason, M. Ólafsson, Proc. WGC, 603-608 (2000)

4. H. Kristmannsdóttir, H. Ármannsson, Aquatic Ecology, 38, 115-128 (2004)

5. Á.E. Sveinbjörnsdóttir, S. Johnsen, S. Arnórsson, Proc. WGC, 1043-1048 (1995)

6. J. Gunnarsson-Robin, A. Stefánsson, S. Ono, P. Torssander, J. Vol. Geoth. Res., 346, 161-179 (2017)

7. P. Torssander, Contrib. Mineral. Petrol., 102, 18-23 (1989)

8. A. Stefánsson, J. D. Barnes, Earth Plan. Sci. Letters, 449, 69-18 (2016)

9. S.A. Halldórsson, J.D. Barnes, A. Stefánsson, D.R. Hilton, E.H. Hauri, E.W. Marshall, Geology, 44, 679-682 (2016)

10. H. Nicholson, M. Condomines, J.G. Fitton, A.E. Fallick, K. Grönvold, G.Rogers, J. Petrology, 32, 1005-1020 (1991) 